\title{
Unified Payment Interface (UPI): A Digital Innovation and Its Impact on Financial Inclusion and Economic Development
}

\author{
Shailesh Rastogi", Chetan Panse, Arpita Sharma, Venkata Mrudula Bhimavarapu \\ Symbiosis Institute of Business Management, Symbiosis International (Deemed University), Pune, India
}

Received January 30, 2021; Revised April 13, 2021; Accepted June 4, 2021

\section{Cite This Paper in the following Citation Styles}

(a): [1] Shailesh Rastogi, Chetan Panse, Arpita Sharma, Venkata Mrudula Bhimavarapu, "Unified Payment Interface (UPI): A Digital Innovation and Its Impact on Financial Inclusion and Economic Development," Universal Journal of Accounting and Finance, Vol. 9, No. 3, pp. 518-530, 2021. DOI: 10.13189/ujaf.2021.090326.

(b): Shailesh Rastogi, Chetan Panse, Arpita Sharma, Venkata Mrudula Bhimavarapu (2021). Unified Payment Interface (UPI): A Digital Innovation and Its Impact on Financial Inclusion and Economic Development. Universal Journal of Accounting and Finance, 9(3), 518-530. DOI: 10.13189/ujaf.2021.090326.

Copyright $\bigcirc 2021$ by authors, all rights reserved. Authors agree that this article remains permanently open access under the terms of the Creative Commons Attribution License 4.0 International License

\begin{abstract}
UPI (Unified Payment Interface) platform has been used especially in India since 2016. This paper is aimed at exploring how UPI is impacting, financial literacy, financial inclusion and the economic development of the poor in India. Structured equation modelling is applied in the paper to explore the path analysis of the relevant construct to establish the relationship. A structured questionnaire of interval scale was administered to gather the data for the study. It is found that UPI is impacting the financial literacy. In addition to that, it is found that financial literacy is significantly impacting financial inclusion which in turn is significantly causing economic development. Moreover, the significant association of financial literacy to financial inclusion is partially mediated by financial stability and the significant association of financial inclusion to economic development is also partially mediated by trust. The main implication of the study is that UPI is helping people in more than one way. It is not only supporting the financial literacy but also contributing to financial inclusion and economic development of the poor, indirectly. Therefore, policy makers can use the findings of this study to frame policies for UPI more effectively in the future. This study is unique as no other study is observed on the linkage of UPI with financial literacy, financial inclusion and economic development of the poor.
\end{abstract}

Keywords UPI, Financial Inclusion, Economic Development, Financial Literacy, Open-API

\section{Introduction}

UPI (Unified Payment Interface) is a digital innovation with an instant payment option developed indigenously in India $[61,86]$. UPI works on a technology known as Open API (Application Programming Interface). API is a type of interface where parties can be linked with each other easily. If there is no entry restriction on the users of an interface, it is called Open-API [38,99]. UPI is based on Open API platform. UPI has been designed in such a way that it serves three broad purposes altogether: 1) it is a mobile-based app; 2) it is linked with AADHAR number; therefore, it can even work without internet; and 3) it is extremely easy to use [61]. Moreover, it has provided huge possibility for innovation and fintech firms can easily integrate with it and provides value added services $[41,60,77,96]$

UPI was launched in India in 2016 with a view that it would provide a platform for everyone in the country an easy and effective tool for digitalization of the payment services $[81,83]$. However, UPI was also linked with GOI (Government of India) as an innovative initiative for the financial inclusion. A set of no frills accounts were open for all the non-banked people and all the accounts were linked with UPI application to support for the financial inclusion using UPI Tewari[93]. However, the real impact 
of UPI need to be ascertained. The resources are always scarce and need to be used wisely. The policy makers and the Government should know whether UPI is really making forays into economic development or not.

There are two policy level initiatives or focus that Government can have regarding UPI. Firstly, UPI can always be used as a tool to support digitalization of the financial services, mainly payment services. Secondly, the focus of Government can be on using UPI for the financial inclusion and economic development of the people. However, before taking a plunge into one of the areas, the government should have a understanding of the impact of UPI on the financial inclusion and economic development of people.

There are no studies which measures the impact of UPI on the financial inclusion in India. UPI can be used in more than one way, which is an innovation to suit the Indian requirement especially to the hoi polloi. The studies which cover UPI are mainly for Open-API and its relevance of the banking or for the financial transaction $[5,6,35,44,99]$. The serious requirement of assessment of the situation study and lack of any study on such lines are the main motivation of this study.

We decided to study the impact of UPI on economic development using structural equation modelling (SEM) approach due to following two main reasons: 1) SEM observes the unobserved variables and helps in identifying the cumulative effect of cause on the output along with taking care of mutual covariance; and 2) UPI and its impact on financial development tend to be in behavioural aspects, which can be better captured by SEM than conventional econometric or deterministic analysis. Therefore, SEM was decided to be used in the model (figure 1).

There are several ways in which this study could have been done using SEM. The theoretical model proposed in the study, which is empirically tested, takes into account the step wise approach. In the first stage, impact of UPI is estimated on financial literacy. In the second step, the impact of literacy is tested on financial inclusion. In the third and final step, the impact of financial inclusion is studied on economic development. In addition to this, the mediating role of financial stability and trust are also taken into account in the broad model.

The main objectives of the study: 1) to assess the impact of UPI on financial literacy and financial inclusion; 2) to explore the effect of UPI on the economic development of the poor via financial literacy and financial inclusion; 3) to evaluate the role of financial stability on the relationship between literacy and financial inclusion; and 4) to evaluate the role of trust on the relationship between financial inclusion and economic development.

The rest of the paper is divided into several sections. The second section after Introduction section dwells upon literature survey on the topic and its constructs. The third section is a detailed discussion of the model to be tested.
The fourth section is a brief related to source of data, time period and main methodology used for the empirical testing of the proposed model. The next section is the Discussion that compares the results of the study with the previous studies and established the contribution and novelty of the results for reasonable implication. The last and the seventh section concludes the study with a discussion on limitation and the future scope of the study.

\section{Review of Literature}

The literature on the topic varies from UPI as a digital innovation, how it plays an important role in solving the issues of digitalization of the payment services to the social impact of the digitalization on the financial services. However, the literature on the topic is on the piece meal basic and does not provide a holistic and cause and effect relationship of UPI to ED, which is done by the current study. The purpose of literature review is to prove that the issue of study of UPI for economic development has never gone ahead of theoretical discussion and confine to descriptive study only. The purpose of this literature review is also to explore the relationship of UPI with other factors to be tested empirically.

The work on UPI has been done theoretically or operationally. In the theoretical studies on UPI, it explores the possible potential of UPI for larger masses and for its benefits for digitalization of the financial services $[42,53,69,94]$. Operational studies using UPI, discusses mainly its operational strength to be accepted as a futuristic tool for digitalization to have the mass appeal [36]. But it is observed by the authors that none of the study empirically talks about the impact of UPI on the economic development of the poor people.

UPI per se is driven by accessibility, convenience, cost and by removing the barriers of financial exclusion $[26,56,70,92,98]$. Cost and barriers of financial inclusion are more significantly contributory factors for fintech to support financial inclusion and economic development $[19,24,26,50,76,98]$.

Fintech, mobile, and other technology drivers are very effective in increasing the financial literacy $[18,43,64,70]$. Similar arguments can be presented for UPI to support financial literacy. ICT (information, communication and technology) also supports economic development $[15,75,80]$. ICT, while supporting economic development, obviously and positively encourages the financial literacy $[52,67]$. This argument is also further corroborated by the evidence that literacy also support the economic development $[28,83]$. Therefore, it is equally pertinent to imply that UPI supports the literacy. Thus, the following hypothesis is formed:

$\mathrm{H}_{1}$ : UPI impacts the literacy (Financial Literacy).

Literature is full of evidence that literacy or financial literacy fully contribute to financial inclusion $[3,29,31,39,40,63,66,89]$. However, there is also evidence 
that financial stability is linked with financial literacy and financial inclusion $[11,27,35,44,54,77]$. Therefore, this study proposes empirically testing the mediating role of financial stability in the financial literacy and financial inclusion:

H2: Financial Stability mediates the relationship between Literacy and financial Inclusion

The role of Financial inclusion to economic development of poor is also equally evident in the literature $[2,21,62,83,88]$. But there is enough evidence to extend the idea that the financial inclusion has its own share of problems to have its full impact on the development $[9,10,15,28,54]$. It is observed by the authors that many-a-problems associated with the smooth transfer of the effects of financial inclusion can be fully achieved if an element of trust exists there [20,22,23,33,51,87,98]. Thus, this study proposes that the following hypothesis needs to be tested empirically:

H3: Trust mediates the relationship between Financial Inclusion and Economic Development.

\section{Theoretical Model and Hypotheses Formulation}

The tenet of this study is two pronged. First, it is believed that the facility of UPI supports the financial literacy. Secondly, it is also believed that UPI pushes for Financial literacy which causes FI to support the ED of the poor (Figure 1). Voluntary Financial Exclusion, Accessibility, Cost and Convenient are the determinants which causes UPI to its present shape. UPI is so cheap and convenient that people are encouraged to use it more often [41]. A policy level change of demonetization also encouraged people to turn to digitalization which eventually help in educating people and financial literacy got supported by it [84]. Covid crisis is another shot in the arm or silver lining in disguise to support the digitalization of payment services [95]

Literature show that there are not many studies on UPI to build up the theory of the linkage of UPI to FL and eventually to FI. However, the closest substitute to UPI can be ICT or Mobile banking, which has many examples suffice to build such theoretical framework. There are many studies which has provided evidence that ICT led to Financial Literacy $[27,43,63]$. Moreover, there is umpteen evidence that ICT led to FI or better standard of $[1,25,55,80]$. In addition to this, there are more supporting literature regarding mobile banking/mobile internet for FI $[52,67,74]$.

The second part of the model is that FL leads to FI which in turn leads to ED of the poor. There are many studies which have emphasized that FL leads to FI $[3,14,32,63]$. Furthermore, literature is replete with the evidence that FI leads to ED [12,13,57,62,71,83,84].

However, causal relationship between FL and FI is mediated by Financial Stability (FS) $[11,78]$. In addition to this, causal relationship between FI and ED is mediated by Trust. The mediation of FS between FL and FI that is quintessential as full effect of FL on FI can be transferred only when some basic levels of financial consistency are presented in the system. In addition, the effect of FL on FI will be there but less in impact. Similarly, the mediation by Trust between FI and ED ensures that FI will actually serve its purpose of ED, however, without trust, the full impact of FI on ED cannot be seen [20,100].

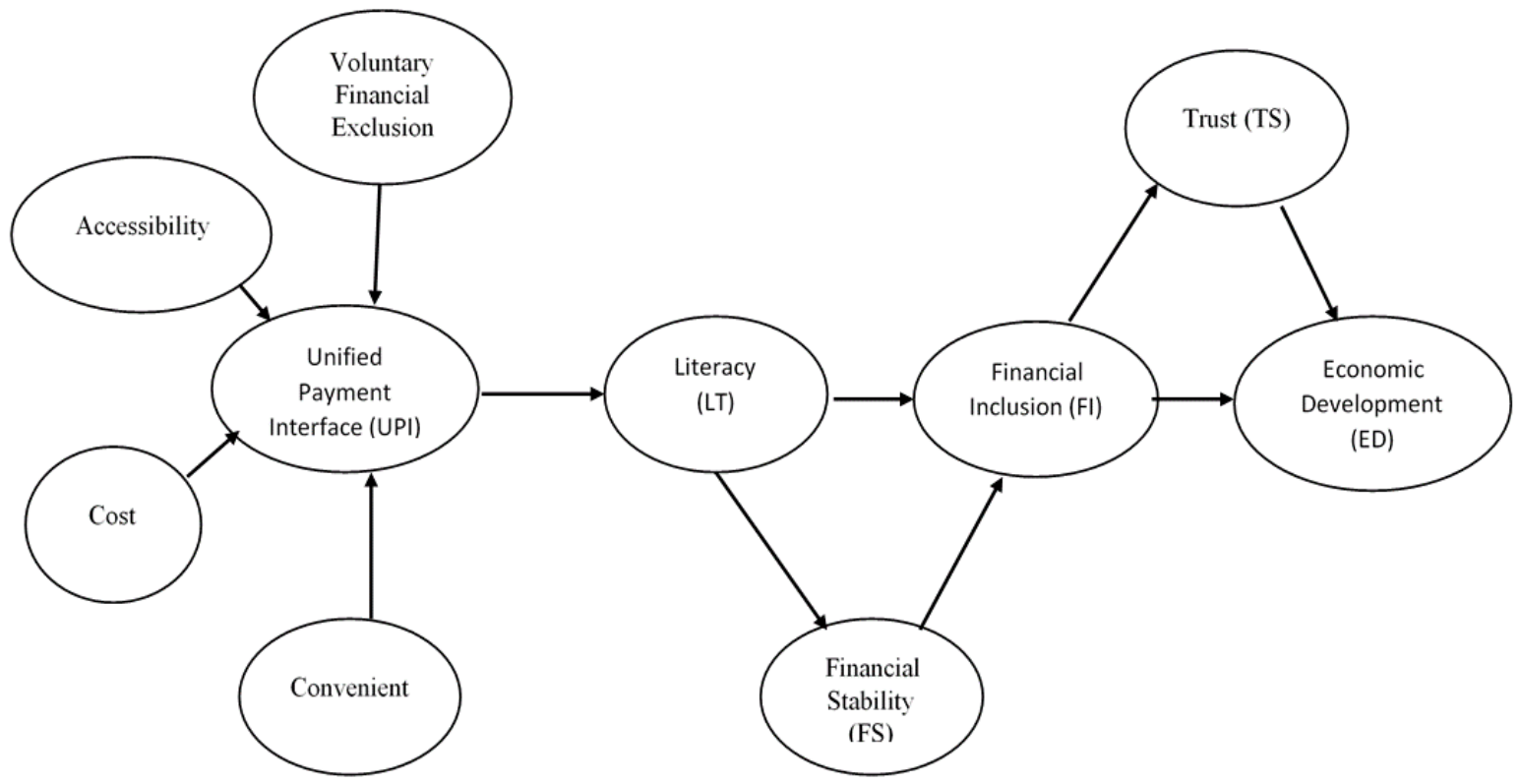

Note: UPI (Unified Payment Interface) is a second order construct. Financial stability (FS) and Trust are mediating constructs and mediating between Literacy (LT) and Financial Inclusion (FI) and Financial Inclusion (FI) and Economic Development (ED) respectively.

Figure 1. Conceptual Model 


\section{Data and Methodology}

We have used a few terms frequently in the current paper. Financial literacy $[3,18,27]$ is one of them. However, FL is not defined universally and unanimously; therefore, we have measured it using a construct (Table 1). Similarly, we have adapted the meaning and context of the variables using the literature for financial stability [11,78]; financial inclusion [37,57,79,83,101]; and financial exclusion $[19,98]$.

A structured questionnaire was administered on 500 odd respondents. The criteria for qualifying the respondent is that he/she should be PMJDY (Pradhan Mantri Jan Dhan Yojana) account holder so that the respondent would have access to basic features of digital transactions and other mainstream of financial or banking services. This is the criteria for the target population. The data is mainly collected from the rural or semi-urban areas of Maharashtra state of India. The rural or semi-urban area was chosen intentionally done so that a greater number of qualified respondents can be approached. We have used convenient non-probability sampling method because of the restrictive definition of the target population. The questions used in the questionnaire are adapted from the literature. The survey was administered during the months of July to December of 2019 under normal conditions.

Structured Equation Modelling (SEM) methodology is applied to empirically test the hypotheses of the study. SEM is a preferred mode of studies on financial inclusion and it impact on the economic development $[34,83]$. The same methodology is being applied in the study. The unobserved variables (latent variables) of relevance and interest are estimated using SEM method $[59,65]$.

SEM can be estimated using two methods: covariance-based SEM (CV-SEM) and partial least square based SEM (PL-SEM) $[45,46]$. However, there are certain situations where PL-SEM should be preferred over CV-SEM $[4,16,17,47,48]$. One of such situations is when the construct has lesser number of indicators (statements) to represent the constructs. The present study fit in under this situation; and therefore, we have used PLS-SEM in this study to do the analysis.

We would like to clarify for the issue of measurement of the variables used in the study. All the variables used in the study are measured with the help of constructs (unobserved variables) (Table 1). A few variables are measured with the help of single indicators. Due to this limitation, we insisted on using PLS SEM which provides the inherent facility to use constructs of even single indicators successfully $[7,48,49]$. The reliability and validity issues of all the constructs are within the acceptable ranges (Table 1); therefore, the current study justifies the use of such constructs.

\section{Results}

Table 1. CFA summary of measurement models

\begin{tabular}{|c|c|c|c|c|}
\hline Construct & Items & $\begin{array}{c}\text { Std Regression } \\
\text { Weight }\end{array}$ & $\begin{array}{c}\text { CR-Composite } \\
\text { Reliability }\end{array}$ & $\begin{array}{c}\text { Average Variance } \\
\text { extracted (AVE) }\end{array}$ \\
\hline Accessibility, Cronbach's alpha $(\alpha)=0.8311$ & $\mathrm{ACC} 1$ & 0.804 & 0.7688 & 0.7365 \\
\hline & $\mathrm{ACC} 2$ & 0.885 & & \\
\hline & $\mathrm{ACC} 3$ & 0.883 & & \\
\hline UPI, Cronbach's alpha $(\alpha)=0.8147$ & $\begin{array}{l}\text { DP1 } \\
\text { DP3 }\end{array}$ & $\begin{array}{l}0.915 \\
0.922\end{array}$ & 0.7379 & 0.8436 \\
\hline Convenient & Conv1 & 1 & & 1.0000 \\
\hline Cost & Cost1 & 1 & & 1.0000 \\
\hline Trust, Cronbacc's alpha $(\alpha)=0.7949$ & $\begin{array}{l}\text { Trust1 } \\
\text { Trust2 } \\
\text { Trust3 }\end{array}$ & $\begin{array}{l}0.798 \\
0.883 \\
0.835\end{array}$ & 0.8773 & 0.7048 \\
\hline Financial Inclusion & FI3 & 1 & & 1.0000 \\
\hline Financial Stability & FS3 & 1 & & 1.0000 \\
\hline Literacy & Lit3 & 1 & & 1.0000 \\
\hline Voluntary Fin Exclusion & Vfi2 & 1 & & 1.0000 \\
\hline Economic Development & ED4 & 1 & & 1.0000 \\
\hline
\end{tabular}

Notes: 1) As Convenient, Cost, Financial Inclusion, Financial Stability, Literacy, Voluntary Fin Exclusion and Economic Development are one item order construct, therefore their CR is not estimated. CR and AVE of all construct is reliable and significant. 2) UPI - Unified Payments Interface 


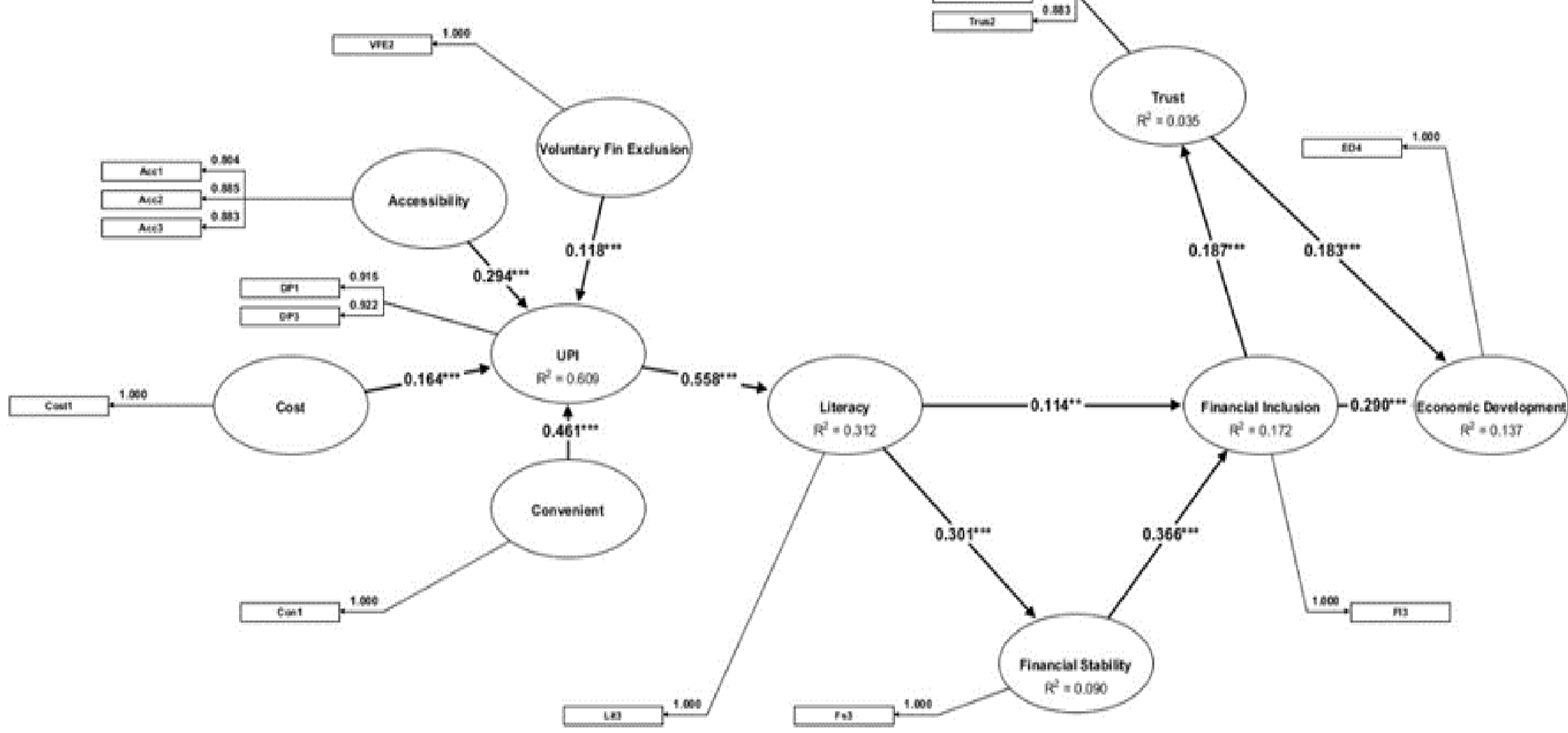

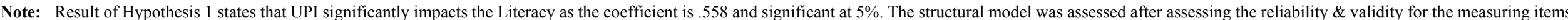

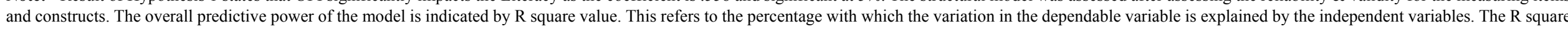

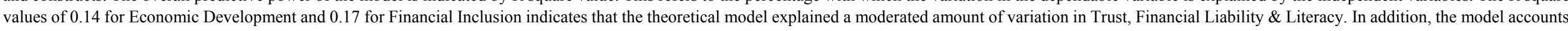
for 61 per cent of variance in UPI towards online

Figure 2. Statistical Model 
Table 2. Descriptive statistics and validity of constructs

\begin{tabular}{|c|c|c|c|c|c|c|c|c|c|c|c|c|}
\hline Construct & Mean & SD & Accessibility & $\begin{array}{l}\text { Digital } \\
\text { Platform }\end{array}$ & Convenient & Cost & Trust & $\begin{array}{l}\text { Financial } \\
\text { Inclusion }\end{array}$ & $\begin{array}{c}\text { Financial } \\
\text { Stability }\end{array}$ & Literacy & $\begin{array}{c}\text { Voluntary } \\
\text { Fin } \\
\text { Exclusion } \\
\end{array}$ & $\begin{array}{c}\text { Economic } \\
\text { Development }\end{array}$ \\
\hline Accessibility & 3.39 & 1.12 & 0.7365 & & & & & & & & & \\
\hline UPI & 2.94 & 1.09 & 0.3420 & 0.8436 & & & & & & & & \\
\hline Convenient & 3.19 & 1.38 & 0.2327 & 0.4902 & 1.0000 & & & & & & & \\
\hline Cost & 2.87 & 1.26 & 0.1624 & 0.3114 & 0.2926 & 1.0000 & & & & & & \\
\hline Trust & 3.51 & 0.94 & 0.3501 & 0.4117 & 0.3696 & 0.2302 & 0.7048 & & & & & \\
\hline Financial Inclusion & 3.75 & 1.07 & 0.0620 & 0.0421 & 0.0614 & 0.0521 & 0.0350 & 1.0000 & & & & \\
\hline Financial Stability & 3.47 & 1.03 & 0.0349 & 0.0523 & 0.1127 & 0.0631 & 0.0604 & 0.1603 & 1.0000 & & & \\
\hline Literacy & 3.31 & 1.18 & 0.1615 & 0.3119 & 0.2734 & 0.1719 & 0.2381 & 0.0503 & 0.0904 & 1.0000 & & \\
\hline $\begin{array}{l}\text { Voluntary Fin } \\
\text { Exclusion }\end{array}$ & 2.26 & 1.17 & 0.0004 & 0.0382 & 0.0057 & 0.0507 & 0.332 & 0.0126 & 0.0000 & 0.0144 & 1.0000 & \\
\hline $\begin{array}{c}\text { Economic } \\
\text { Development }\end{array}$ & 3.98 & 1.00 & 0.0264 & 0.0448 & 0.0618 & 0.0155 & 0.0564 & 0.1050 & 0.0890 & 0.0426 & 0.0069 & 1.0000 \\
\hline
\end{tabular}

Note: 1) Squared correlations; AVE in the diagonal. All the constructs are having highest diagonal values and therefore have sustained Discriminant validity. 
The results of the analysis are presented in the pictorial form with the help of structural figure of the model (Figure 2). The summary of the measurement model is reported in the Table 1. Total 10 factors with 15 items converging in to it were retained in the model. The standard statistical procedures were followed and fifteen items were dropped due to low loadings $\&$ cross -loadings [45]. The value of Cronbach's alpha was above 0.7 as recommended for three constructs while for other constructs only one item was used. Later on, the measurement model was tested for reliability and validity. Table 1 depicts the final item with standardised regression weights (all above 0.798), the composite reliability (all above 0.7379) and the AVE for each of the item [30].

Table 2 shows discriminant validity statistics such as inter-correlations and the square root of average variance extracted. Inter-correlations are below 0.5, thus Multicollinearity is not a concern in the present data [91]. The model demonstrates evidence of convergent validity (significant loadings, CR $>0.7$, AVE $>0.5$ for all the constructs) and discriminant validity (square root of AVE of each construct $>$ the correlations with other constructs) as shown on diagonal line $[8,30,45]$.

Mediation analysis was performed using PROCESS to access the role of Financial Stability. The outcome variable was Financial Inclusion. The predictor variable was Literacy. The indirect effect of Financial Stability was found significant on Financial inclusion (Indirect Effect $0.0996,95 \%$ CI $0.0680-0.1371$ ). Also, the direct effect $(0.1034,95 \%$ CI $0.0274-0.1793)$ is significant. Hence, we can conclude that the partial mediation of Financial Stability has an effect on Financial Inclusion (Table 3, Part A).

Mediation analysis was performed using PROCESS to access the role of Trust. The outcome variable was Economic Development. The predictor variable was Financial Inclusion. The indirect effect of Trust was found significant on Economic Development (Indirect Effect $0.0309,95 \%$ CI $0.0130-0.0539$ ). Also, the direct effect $(0.2719,95 \%$ CI $0.1940-0.3498)$ is significant. Hence, we can conclude that the partial mediation of Trust has an effect on Economic Development (Table 3, Part B)

Table 3. Hypothesis Testing and Total, direct and indirect effect

\begin{tabular}{ccccc}
\hline Part A & & & & \\
\hline Relationship & $\beta$ & t-value & LLCI & ULCI \\
LITERACY ---> FI (Direct effect) & $.1034^{*}$ & 2.6749 & .0274 & .1793 \\
LITRACY --> FS & $.2610^{*}$ & 7.0481 & .1882 & .3337 \\
FS --> FI & $.3816^{*}$ & 8.5723 & .2941 & .4691 \\
H2: LITRACY --> FS --> FI (Indirect Effect) & $.0996^{*}$ & ---- & .0680 & .1371 \\
Effect & $\beta$ & t-value & LLCI & ULCI \\
Total effect model & $0.2030^{*}$ & 5.1463 & .1255 & .2805 \\
Direct effect & $.1034^{*}$ & 2.6749 & .0274 & .1793 \\
Indirect effect & $.0996^{*}$ & ---- & .0680 & .1371 \\
\hline
\end{tabular}

Part B

\begin{tabular}{ccccc}
\hline Relationship & $\beta$ & t-value & LLCI & ULCI \\
FI --> ED (Direct effect) & $.2719^{*}$ & 6.8550 & .1940 & .3498 \\
FI --> TRUST & $.1775^{*}$ & 4.3554 & .0974 & .2575 \\
TRUST --> ED & $.1739^{*}$ & 4.0708 & .0900 & .2579 \\
H3: FI --> TRUST --> ED (Indirect Effect) & $.0309^{*}$ & ----- & .0680 & .1371 \\
& Effect & $\beta$ & LLCI & ULCI \\
Total effect model & $0.3028^{*}$ & 7.6854 & .02251 & .3804 \\
Direct effect & $.2719^{*}$ & 6.8550 & .01940 & .3498 \\
Indirect effect & $.0309^{*}$ & ---- & .0130 & .0539 \\
\hline \hline
\end{tabular}

Notes: *significant. Direct effect of Financial Inclusion on Economic Development is also significant. This implies that there is a partial mediation effect in the model. 


\section{Discussion and Implication}

\subsection{Explanation on Hypothesis Testing Results}

As discussed in the results section, the study tests three major hypotheses. All the three hypotheses, H1, H2 and, H3 have been confirmed (Table 3) to be a suitable model (figure 2) relative to the model proposed in the Figure 1. The model shows that all the constructs have strong validity and reliability (Table 2). The hypothesis of the study is strongly supported by the literature.

\subsection{Comparison of the Results}

Reference $[72,73]$ studies the digital innovation and the financial inclusion and highlights an urgent need of scholarly attention to the financially excluded group for finding out the impact of the digital innovation. They find that users of the services are high-income households. The current study thus takes the poor beneficiaries into consideration who needs financial inclusion.

The existing studies see impact of the mobile technology on the financial inclusion. $[58,68,82]$ studies the digital innovation that is restricted to the development of credit cooperative. Reference [90] studies the fin tech platform with banking industry. But the current study focuses more on the financial inclusion and derivers of the technology platforms. Reference [83] studies the online banking, and drivers of financial literacy and Financial inclusion, but such programming interface was missing.

Reference [85] has discussed the mediating effect of financial literacy on the open banking and financial inclusion. Open banking refers to the integration of the technology and the banks. The association of the open banking and financial literacy, is enforced in some studies $[37,85]$ identifies the infrastructural gaps in the policy implementation for the poor under the financial inclusion. This gap is answered in the current study.

\subsection{Contribution of the Present Paper}

The importance of the studies done in the area of financial inclusion shows its impact on the ultimate aim of reaching the economic development. The current study brings out the peripheral factors which affects the financial inclusion and the relationship between the financial inclusion and the economic development. One of the innovations in the area of financial technology is the use of UPI. UPI is considered as the biggest innovation in the digital banking. An innovation of this sort is required to make the digital ecosystem. A digital ecosystem helps the financial inclusion which is a major contribution to this paper (Figure 2). The study finds that the major drivers which support the sustainability of the UPI platform are accessibility to the technology, convenience, cost effective and citizens voluntary exclusion in the financial inclusion.

The presence of such digital ecosystem will help in increasing the financial literacy of the individuals. If the individuals are financially literate, they use more financial services and become a part of the financial ecosystem which is supported by the underlying digital ecosystem. The current study finds that the relationship of the financial literacy and the financial inclusion is mediated by the financial stability. The study also finds and concludes that the association of the financial inclusion and the economic development is mediated by the trust. A large amount of trust in the financial system by the bottom of the pyramid will strengthen the economy.

\subsection{Implications (Policy as well as Managerial)}

The area of digitization, financial inclusion and economic development attracts many policy makers and managers.

The first major implication is to provide the digital platform in the economy. The availability of the technology and the sustainability requires the government's intermediation. The government with the financial regulators should provide platforms like UPI. But just providing the platform is not enough; the success lies behind the accessibility of these services. The government should see and if required intervene the markets to see if the beneficiary is getting the services in the best price or in a cost-effective way. The convenience with voluntary financial inclusion, thus positively impacting the success of these services (UPI). The firms on the other side should design and innovate their services, by providing such interphase (UPI) for the beneficiaries and clients. It is observed in the microfinance sector that the presence of the digital platforms has led to greater reach of the poor in the financial system.

The second major implication from the study is to develop the infrastructure for the promotion of financial literacy. In these areas the government and regulators are doing good. But certain economies and regions still face the dearth, because of the unavailability of proper infrastructure related to the electrification, internet speed, and institutions with orientation to educate the poor. So, the government should make policy related to promotion of financial literacy programs by the institutions who are also providing the financial services. It's the manager's duty to educate the client and maintain more transparent so the trust can be maintained.

The third major implication is the presence of stability and trust which promotes the financial inclusion and further the economic development. The UPI and financial inclusion together will multiply the developmental effect. But the government regulation which can mitigate the level of asymmetric information in the financial markets will boost the trust and confidence among the untouched clients which can contribute a lot to the GDP and to the 
development of the economy.

Therefore, authors would like to recommend digitalization through UPI to support the financial literacy and eventually FI and ED of the poor in the country. Moreover, such ambitious goals can never be achieved unless some amount of stability in the policy and trust is built. To build the stability, policy level changes should be taken after due consultation with all the stakeholders so that sustainable and stable solutions can be expected. Furthermore, to build trust, a generous customer care should be established which ensure appropriate and urgent reporting of the grievances of the people and its timely redressal.

\section{Conclusion, Limitation and Future Scope}

The study provides an addition in the literature of financial inclusion and economic development. Considering an innovative variable of UPI in the area of digital finance and financial inclusion, the paper shows how financial stability and trust mediates act as determinants of the financial inclusion and economic development respectively.

The advent of digitalization itself is a path-breaking innovation, and UPI is one such innovation which supports the digital ecosystem and contributes to the inclusion of the bottom of the pyramid into the financial system. The paper concludes that UPI even gives safe transaction to the individuals who hold PMJDY accounts. If these individuals will transact through these programming interphases, this will help their inclusion in the financial system and leads to economic development.

The paper can be taken on another level by extending the scale of the study, and by taking more determinants into account. The study can be done in multiple settings with different economic cycles, and the reliability of the study can be tested. The factors like government intervention and the inclusion of informal sector can also be considered. Behavioural factors can also be studied under the digital innovation and financial inclusion.

\section{REFERENCES}

[1] Adam, L., "Electronic communications technology and development of Internet in Africa", Information Technology for Development, Vol. 7 No. 3, pp. 133-144, 1996, DOI: 10.1080/02681102.1996.9525278

[2] Adeola, O. \& Evans, O., "Financial inclusion, financial development, and economic diversification in Nigeria", The Journal of Developing Areas, Vol. 51 No. 3, pp. 1-15, 2017. DOI: $10.1353 /$ jda.2017.0057

[3] Agarwal, T., "Twin Pillars of Indian Banking: Financial
Literacy and Financial Inclusion", SIES Journal of Management, Vol. 12 No. 2, pp. 3-12, 2016. http://search.ebscohost.com/login.aspx?direct=true $\& \mathrm{db}=\mathrm{bs}$ $\mathrm{u} \& \mathrm{AN}=125094775 \&$ site $=$ ehost-live

[4] Ali, F., Rasoolimanesh, S., Sarstedt, M., Ringle, C. \& Ryu, K., "An assessment of the use of partial least squares structural equation modeling (PLS-SEM) in hospitality research", International Journal of Contemporary Hospitality Management, Vol. 30 No. 1, pp. 514-538, 2018. DOI: 10.1108/IJCHM-10-2016-0568

[5] Almehrej, A., Freitas, L. \& Modesti, P. Account and Transaction Protocol of the Open Banking Standard. In: RASCHKE, A., MÉRY, D. \& HOUDEK, F., eds. Rigorous State-Based Methods, Cham. Springer International Publishing, 2020, pp. 230-236. https://doi.org/10.1007/978 -3-030-48077-6_16

[6] Ann, C. W. S. \& Iqbal, N. M., "Open Application Programming Interface (API): A Financial Revolution", Bank Negara Malaysia Quarterly Bulletin, Vol. 4, pp. 51-57, 2017.

https://www.bnm.gov.my/documents/20124/770512/p8_fa 1.pdf

[7] Astrachan, C. B., Patel, V. K. \& Wanzenried, G., "A comparative study of CB-SEM and PLS-SEM for theory development in family firm research", Journal of Family Business Strategy, Vol. 5 No. 1, pp. 116-128, 2014. DOI: 10.1016/j.jfbs.2013.12.002

[8] Bagozzi, R. P. \& Yi, Y., "On the evaluation of structural equation models", Journal of the academy of marketing science, Vol. 16 No. 1, pp. 74-94, 1988. https://doi.org/10.1007/BF02723327

[9] Bartik, T. J., "Solving the Problems of Economic Development Incentives", Growth and Change, Vol. 36 No. 2, pp. 139-166, 2005. DOI: 10.1111/j.1468-2257.2005.002 72.x

[10] Basu, S., "Structural Problems in Financing Development: Issues Relating to India", International Review of Applied Economics, Vol. 20 No. 1, pp. 85-101, 2006. DOI: $10.1080 / 02692170500362793$

[11] Batuo, M., Mlambo, K. \& Asongu, S., "Linkages between financial development, financial instability, financial liberalisation and economic growth in Africa", Research in International Business and Finance, Vol. 45, pp. 168-179, 2018. DOI: 10.1016/j.ribaf.2017.07.148

[12] Bhave, D. G., "A study of development towards financial inclusion in India", Journal of Commerce and Management Thought, Vol. 5 No. 2, pp. 229-240, 2014. DOI: 10.5958/j.0976-478X.5.2.017

[13] Blanco, L., "Finance, Growth, and institutions in Latin America: what are the Links?", Latin American journal of economics,Vol. 50 No. 2, pp. 179-208, 2013. https://scielo.conicyt.cl/scielo.php?pid=S0719-043320130 00200002\&script $=$ sci_arttext\&tlng=e

[14] Cámara, N. \& Tuesta, D., "Factors that matter for financial inclusion: Evidence from Peru", Aestimatio, Vol. 10 No. 1 , pp. 10-31, 2015. DOI: 10.5605/IEB.10

[15] Chaudhuri, A., "ICT for Development: solutions seeking problems?", Journal of Information Technology, Vol. 27 
No. 4, pp. 326-338, 2012. DOI: 10.1057\%2Fjit.2012.19

[16] Chin, W. W., "The partial least squares approach to structural equation modeling", Modern methods for business research, Vol. 295 No. 2, 1998, pp. 295-336. file://C:/Users/HP/Downloads/1998ThePartialLeastSquare sApproachtoSEMchapter\%20(2).pdf

[17] Chin, W. W., Marcolin, B. L. \& Newsted, P. R., "A partial least squares latent variable modeling approach for measuring interaction effects: Results from a Monte Carlo simulation study and an electronic-mail emotion/adoption study", Information systems research, Vol. 14 No. 2, pp. 189-217, 2003. DOI: 10.1287/isre.14.2.189.16018

[18] Chlouba, T., Šimková, M. \& Němcová, Z., "Application for education of financial literacy", Procedia-Social and Behavioral Sciences, Vol. 28 No. 1, pp. 370-373, 2011. DOI: $10.1016 /$ j.sbspro.2011.11.070

[19] Cnaan, R. A., Moodithaya, M. \& Handy, F., "Financial inclusion: lessons from rural South India", Journal of Social Policy,Vol. 41 No. 1, pp. 183-205, 2012. DOI: $10.1017 / \mathrm{S} 0047279411000377 \% 20$

[20] Courbe, J., "Building 'Open Banking' on a Platform of Trust", American Bankers Association. ABA Banking Journal, Vol. 110 No. 4, pp. 38, 2018. https://www.proquest.com/openview/9ae33150825844ba7 15e10f9537a1b80/1?pq-origsite $=$ gscholar $\& \mathrm{cbl}=47754$

[21] Cull, R., Ehrbeck, T. \& Holle, N., "Financial inclusion and development: Recent impact evidence", Focus Note, Vol. 92, pp. 1-12, 2014.

https://www.cgap.org/sites/default/files/FocusNote-Financi al-Inclusion-and-Development-April-2014.pdf

[22] De Koker, L. \& Jentzsch, N., "Financial inclusion and financial integrity: Aligned incentives?", World development, Vol. 44 No. 1, pp. 267-280, 2013. DOI: 10.1016/j.worlddev.2012.11.002

[23] Dearmon, J. \& Grier, K., "Trust and development", Journal of Economic Behavior \& Organization, Vol. 71 No. 2, pp. 210-220, 2009. DOI: 10.1016/j.jebo.2009.02.011

[24] Dev, S. M., "Financial inclusion: Issues and challenges", Economic and political weekly, Vol. 41 No. 41, pp. 4310-4313, 2006. https://www.jstor.org/stable/4418799

[25] Donovan, K., "Mobile money for financial inclusion", Information and Communications for development, Vol. 61 No. 1, pp. 61-73, 2012. DOI: 10.1596/978-0-8213-8991-1

[26] Dos Santos, P. L. \& Kvangraven, I. H., "Better Than Cash, but Beware the Costs: Electronic Payments Systems and Financial Inclusion in Developing Economies", Development and Change, Vol. 48 No. 2, pp. 205-227, 2017. DOI: $10.1111 /$ dech. 12296

[27] Elsinger, H., Fessler, P., Feyrer, J., Richter, K., Silgoner, M. A. \& Timel, A., "Digitalization in financial services and household finance: fintech, financial literacy and financial stability", Financial Stability Report, Vol. 35 No. 1, pp. 50-58, 2018.https://ideas.repec.org/a/onb/oenbfs/y2018i35 b1.html

[28] Feldman, M., Hadjimichael, T., Lanahan, L. \& Kemeny, T., "The logic of economic development: a definition and model for investment", Environment and Planning C:
Government and Policy, Vol. 34 No. 1, pp. 5-21, 2016. DOI: $10.1177 \% 2 \mathrm{~F} 0263774 \mathrm{X} 15614653$

[29] Fernandes, D., Lynch Jr, J. G. \& Netemeyer, R. G., "Financial literacy, financial education, and downstream financial behaviors", Management Science, Vol. 60 No. 8, pp. 1861-1883, 2014. DOI: 10.1287/mnsc.2013.1849

[30] Fornell, C. \& Larcker, D. F., "Evaluating structural equation models with unobservable variables and measurement error", Journal of marketing research, Vol.18 No. 1, pp. 39-50, 1981. DOI: $10.1177 \% 2 F 0022243781018$ 00104

[31] Frączek, B., Bobenič Hintošová, A., Bačová, M. \& Siviček, T., "Simultaneous use of the financial literacy level and the financial inclusion degree as a result of financial education efficiency in Visegrad Group countries", Journal of Economics \& Management, Vol. 27 No. 1, pp. 5-25, 2017 a. DOI: $10.22367 /$ jem.2017.27.01

[32] Frączek, B., Hintošová, A. B., Bačová, M. \& Siviček, T., "Simultaneous use of the financial literacy level and the financial inclusion degree as a result of financial education efficiency in Visegrad Group countries", Journal of Economics \& Management, Vol. 27 No. 1, pp. 5-25, 2017 b. DOI: $10.22367 /$ jem.2017.27.01

[33] Francois, P. \& Zabojnik, J., "Trust, social capital, and economic development", Journal of the European Economic Association, Vol. 3 No. 1, pp. 51-94, 2005. DOI: $10.1162 / 1542476053295304$

[34] Fungáčová, Z. \& Weill, L., "Understanding financial inclusion in China", China Economic Review, Vol. 34, pp. 196-206, 2015. DOI: 10.1016/j.chieco.2014.12.004

[35] Giloth, R., "Philanthropy and Economic Development: New Roles and Strategies", Economic Development Quarterly, Vol. 33 No. 3, pp. 159-169, 2019. DOI: $10.1177 \% 2 \mathrm{~F} 0891242419839464$

[36] Gochhwal, R., "Unified Payment Interface-An Advancement in Payment Systems", American Journal of Industrial and Business Management, Vol. 7 No. 10, pp. 1174-1191, 2017. DOI: 10.4236/ajibm.2017.710084

[37] Gogia, J. \& Agrawal, J., "Mobile Financial Services: Technology Initiatives toward Financial Inclusion", Productivity, Vol. 56 No. 4, pp. 345, 2016. http://search.ebscohost.com/login.aspx?direct=true $\& \mathrm{db}=\mathrm{bs}$ $\mathrm{u} \& \mathrm{AN}=114123466 \&$ site $=$ ehost-live.

[38] Gozman, D., Hedman, J. \& Olsen, K. S. Open Banking: Emergent Roles, Risks \& Opportunities. ECIS, 2018. 183. http://ecis2018.eu/

[39] Grohmann, A., Klühs, T. \& Menkhoff, L., "Does financial literacy improve financial inclusion? Cross country evidence", World Development, Vol. 111, pp. 84-96, 2018. DOI: $10.1016 /$ j.worlddev.2018.06.020

[40] Grohmann, A. \& Menkhoff, L., "Financial literacy promotes financial inclusion in both poor and rich countries", DIW Economic Bulletin, Vol. 7 No. 41, pp. 399-407, 2017. http://hdl.handle.net/10419/170500

[41] Guibaud, S., "How to develop a profitable, customer-focused digital banking strategy: Open banking services and developer-friendly APIs", Journal of Digital 
Banking, Vol. 1 No. 1, pp. 6-12, 2016. https://www.ingentaconnect.com/content/hsp/jdb001/2016/ 00000001/00000001/art00002

[42] Gupta, S. \& Kumar, D., "UPI-An Innovative Step For Making Digital Payment Effective And Consumer Perception On Unified Payment Interface", The International Journal of analytical and experimental modal analysis, Vol. 12 No. 1, pp. 2482-2491, 2020. http://ijaema.com/gallery/284-january-3313.pdf

[43] Guria, L. S., Patankar, R. \& Tyagi, D., ICT-Based Financial and Investor Literacy through Common Service Centres. Proceedings of the 10th International Conference on Theory and Practice of Electronic Governance, pp 532-533, 2017. DOI: $10.1145 / 3047273.3047369$

[44] Ha, D., Gillet, P., Le, P. \& Vo, D.-T., "Banking integration in ASEAN-6: An empirical investigation", Economic Modelling, Vol. 91, pp. 705-719, 2019. http://www.sciencedirect.com/science/article/pii/S0264999 319300197

[45] Hair, J., Black. Wc, Babin., Bj, Anderson Re., "Multivariate data analysis, a global perspective", New Jersey. Pearson. Ed, Vol. 7, 2010, pp. 816.

[46] Hair, J. F., Black, W. C., Babin, B. J., Anderson, R. E. \& Tatham, R. L., "Multivariate data analysis", Upper Saddle River, NJ: Pearson Prentice Hall, Vol.6, 2006.

[47] Hair, J. F., Ringle, C. M. \& Sarstedt, M., "PLS-SEM: Indeed a silver bullet", Journal of Marketing theory and Practice, Vol. 19 No. 2, pp. 139-152, 2011. DOI: 10.2753/MTP1069-6679190202

[48] Hair, J. F., Risher, J. J., Sarstedt, M. \& Ringle, C. M., "When to use and how to report the results of PLS-SEM", European Business Review, Vol. 31 No. 1, pp. 2-24, 2019. DOI: 10.1108/EBR-11-2018-0203

[49] Hair Jr, J. F., Hult, G. T. M., Ringle, C. \& Sarstedt, M.., "A primer on partial least squares structural equation modeling (PLS-SEM)", Sage publications, 2016.

[50] Hansen Henten, A. \& Maria Windekilde, I., "Transaction costs and the sharing economy", info, Vol. 18 No. 1, pp. 1-15, 2016. DOI: 10.1108/info-09-2015-0044

[51] Hillman, S. \& Neustaedter, C., "Trust and mobile commerce in North America", Computers in Human Behavior, Vol. 70, pp. 10-21, 2017. DOI: 10.1016/j.chb.2016.12.061

[52] Hinson, R. E., "Banking the poor: The role of mobiles", Journal of Financial Services Marketing, Vol. 15 No. 4, pp. 320-333, 2011. DOI: 10.1057/fsm.2010.29

[53] Kakadel, R. B. \& Veshne, N. A., "Unified Payment Interface (UPI)-A Way Towards Cashless Economy", International Research Journal of Engineering and Technology, Vol. 4 No. 1, pp. 762-766, 2017. https://www.irjet.net/archives/V4/i11/IRJET-V4I11136.pd $\mathrm{f}$

[54] Kavya, T. \& Shijin, S., "Economic development, financial development, and income inequality nexus", Borsa Istanbul Review, Vol. 20 No.1, pp 80-93, 2020. DOI: 10.1016/j.bir.2019.12.002

[55] Kenney, G. I., "The missing link - information",
Information technology for development, Vol. 6 No. 1, pp. 33-38, 1995. DOI: 10.1080/02681102.1995.9525254

[56] Khaki, A. R. \& Sangmi, M.-U.-D., "Does access to finance alleviate poverty? A case study of SGSY beneficiaries in Kashmir Valley", International Journal of Social Economics, Vol. 44 No. 8, pp. 1032-1045, 2017. DOI: 10.1108/IJSE-10-2015-0277

[57] Kim, D.-W., Yu, J.-S. \& Hassan, M. K., "Financial inclusion and economic growth in OIC countries", Research in International Business and Finance, Vol. 43, pp. 1-14, 2018. DOI: $10.1016 /$ j.ribaf.2017.07.178

[58] Klein, M., \& Mayer, C., "Mob. bkg. \& Fin. Incl.: The regulatory lessons", The World Bank, No. 5664, 2011. https://ssrn.com/abstract $=1846305$

[59] Kline, R. B., Principles and Practice of Structural Equation Modeling, Guilford Publications, London, 2011.

[60] Kolychev, A. \& Zaytsev, K., "Studying Open Banking Plateforms With Open Source Code", Journal of Theoretical and Applied Information Technology, Vol. 97 No. 11, pp 3038-3052, 2019. http://www.jatit.org/volumes/ Vol97No12/8Vol97No12.pdf

[61] KPMG (2018). Bharat Bill Payment System. Retrieved from

https://assets.kpmg/content/dam/kpmg/in/pdf/2018/03/Bha ratBillPaymentSystem.pdf

[62] Laha, A., "Association between financial inclusion and human development in South Asia: a cross-country analysis with special reference to India", Journal of Economic Policy and Research, Vol. 10 No. 2, pp. 69-93, 2015. file:///C:/Users/HP/Downloads/JEPRonFinancialInclusiona ndHumanDevelopmentinSouthAsia.pdf.

[63] Lalrinmawia, M. \& Gupta, H., "Literacy and Knowledge: Farmers' Financial Inclusion Feasibility", SCMS Journal of Indian Management, Vol. 12 No. 3, pp. 17-24, 2015. https://www.proquest.com/scholarly-journals/literacy-kno wledge-farmers-financial-inclusion/docview/1721916592/s e-2? accountid $=201395$

[64] Leong, C., Tan, B., Xiao, X., Tan, F. T. C. \& Sun, Y. (2017), "Nurturing a FinTech ecosystem: The case of a youth microloan startup in China", International Journal of Information Management, Vol. 37 No. 2, pp. 92-97, 2017. DOI: $10.1016 /$ j.ijinfomgt.2016.11.006

[65] Lomax, R. G. \& Schumacker, R. E., A beginner's guide to structural equation modeling, Mahwah, NJ, psychology press, 2004.

[66] Lusardi, A., Mitchell, O. S. \& Curto, V., "Financial literacy among the young", Journal of consumer affairs, Vol. 44 No. 2, pp. 358-380, 2010. DOI: 10.1111/j.1745-6606.2010.011 73.x

[67] Madon, S., "The Internet and socio-economic development: exploring the interaction", Information technology \& people,Vol. 13 No. 2, pp. 85-101, 2000. DOI: $10.1108 / 09593840010339835$

[68] Mago, S., \& Chitokwindo, S., "The impact of mob. bkg. on Fin Incl in ZI.: A case for Masvingo Prov", Mediterranean Jnl. of Soc. Sci., Vol. 5 No. 9, pp 221-230, 2014. DOI: 10.5901/mjss.2014.v5n9p221 
[69] Mohapatra, S., "Unified Payment Interface (UPI): A Cashless Indian e-Transaction Process", International Journal of Applied Science and Engineering, Vol. 5 No. 1, pp. 29-42, 2017. DOI:10.5958/2322-0465.2017.00004.1

[70] Munyegera, G. K. \& Matsumoto, T., "ICT for financial access: Mobile money and the financial behavior of rural households in Uganda", Review of Development Economics, Vol. 22 No. 1, pp. 45-66, 2018. DOI: $10.1111 /$ rode. 12327

[71] Nair, M. S., "Financial Inclusion vis-à-vis Economic Efficiency: The Case of Commercial Banks in India", Productivity, Vol. 55 No. 4, pp. 338-351, 2015. http://search.ebscohost.com/login.aspx?direct $=$ true $\& d b=b s$ $\mathrm{u} \& \mathrm{AN}=114109082 \&$ site $=$ ehost-live

[72] Nan, W. V., \& Markus, M. L., "Is Incl. Digital Innv. Incl. ? An Investgn.of M-Shwari in Kenya. In Intl. Conf. on Social Implicns. of Comp. in Dvping. Countries", Springer, Cham., 2019, pp. 460-471.

[73] Nan, W., "Who Are the Users of Digital Innov. for Fin. Incl.? The Case of M-Shwari", 2018. https://aisel.aisnet.org/amci s2018/GlobalDev/Presentations/11/

[74] Ndlovu, I. \& Ndlovu, M., "Mobile banking the future to rural financial inclusion: Case study of Zimbabwe", IOSR Journal of Humanities and Social Science, Vol. 9 No. 4, pp. 70-75, 2013.

https://citeseerx.ist.psu.edu/viewdoc/download?doi=10.1.1 $.1086 .2416 \&$ rep $=$ rep $1 \&$ type $=$ pdf

[75] Niebel, T., "ICT and economic growth-Comparing developing, emerging and developed countries", World Development, Vol. 104, pp. 197-211, 2018. DOI: 10.1016/j.worlddev.2017.11.024

[76] North, D. C., "A transaction cost theory of politics", Journal of theoretical politics, Vol. 2 No. 4, pp. 355-367, 1990. DOI: $10.1177 \%$ 2F0951692890002004001

[77] Omarini, A. E., "Banks and fintechs: how to develop a digital open banking approach for the bank's future", Vol. 11 No. 9, pp 23-36, 2018. DOI: 10.5539\%2Fibr.v11n9p23

[78] Ozili, P. K., "Impact of digital finance on financial inclusion and stability", Borsa Istanbul Review, Vol. 18 No. 4, pp. 329-340, 2018. DOI: 10.1016/j.bir.2017.12.003

[79] Ozili, P. K., "Financial inclusion research around the world: A review", Forum for Social Economics, Vol. No., pp. 1-23, 2020. DOI: $10.1080 / 07360932.2020 .1715238$

[80] Palvia, P., Baqir, N. \& Nemati, H., "ICT for socio-economic development: A citizens' perspective", Information \& Management, Vol. 55 No. 2, pp. 160-176, 2018. DOI: 10.1016/j.im.2017.05.003

[81] Panse, C., S., Sharma, A. \& Dorji, N., "Understanding consumer behaviour towards utilization of online food delivery platforms", Journal of Theoretical and Applied Information Technology, Vol. 97 No. 16, pp. 4353-4365, 2019. http://www.jatit.org/volumes/Vo197No16/11Vo197No16.p df

[82] Popova, L. V., Daeva, T. V., Dugina, T. A., Melikhov, V. A., \& Chekrygina, T. A., "Digital Innovn. in Trdnl. Svcs. of Cr. Cooperative. In Frontier Info Tech. \& Sys. Res. in
Cooperative Eco." „Springer, Cham., pp. 477-485.2021. DOI: 10.1007/978-3-030-57831-2_50

[83] Rastogi, S. \& Ragabiruntha, E., "Financial inclusion and socioeconomic development: gaps and solution", International Journal of Social Economics, Vol. 45 No. 7, pp. 1122-1140, 2018. DOI: 10.1108/IJSE-08-2017-0324

[84] Rastogi, S., Suresh, V. \& Leonard, D., "FINANCIAL INCLUSION AND DEMONETIZATION: AN EMPIRICAL STUDY USING EXPLORATORY FACTOR ANALYSIS", Indian Journal of Commerce and Management Studies, Vol. 8 No. 1(5), pp. 38-46, 2017. file:///C:/Users/HP/Downloads/AStudyonFinancialInclusio ninIndia.pdf

[85] Rastogi, S., Sharma, A., \& Panse, C., "Opn. Bkg. \& Incl. Gwth. in Ind. Ind.", Jnl. of Ecology, Vol. 47 No. SI9, pp.75-79, 2020. https://www.researchgate.net/profile/Shail esh-Rastogi/publication/340849253 Open Banking and I nclusive_Growth_in_India/links/5ea-08b3792851c87d 1 ace b69/Open-Banking-and-Inclusive-Growth-in-India.pdf

[86] RBI (2010). RBI Annual Report. Retrieved from: https://www.rbi.org.in/scripts/AnnualReportPublications.a spx?year=2011

[87] Sanderson, A., Mutandwa, L. \& Le Roux, P., "A review of determinants of financial inclusion", International Journal of Economics and Financial Issues, Vol. 8 No. 3, pp. 1-8, 2018.

https://www.proquest.com/docview/2056362329?pq-origsi te $=$ gscholar \& fromopenview $=$ true $\#$

[88] Sarma, M. \& Pais, J., "Financial inclusion and development", Journal of international development, Vol. 23 No. 5, pp. 613-628, 2011. DOI: 10.1002/jid.1698

[89] Servon, L. J. \& Kaestner, R., "Consumer financial literacy and the impact of online banking on the financial behavior of lower - income bank customers", Journal of Consumer Affairs, Vol. 42 No. 2, pp. 271-305, 2008. DOI: 10.1111/j.1745-6606.2008.00108.x

[90] Söylemez, S. A. \& Ahmed, A.-H., "The Role of New Economy Indicators on Banking Sector Performance in Ghana: Trend and Empirical Research Analysis of Banks' Clients and Experts Perception", Journal of Finance and Economics, Vol. 7 No. 1, pp. 23-35, 2019. DOI:10.12691/jfe-7-1-3

[91] Tabachnick, B. G. \& Fidell, L. S., "Principal components and factor analysis", Using multivariate statistics, Vol. 4 No. 1, 2001, pp. 582-633.https://www.pearsonhighered.com/as sets/preface/0/1/3/4/0134790545.pdf

[92] Teo, A.-C., Tan, G. W.-H., Ooi, K.-B., Hew, T.-S. \& Yew, K.-T., "The effects of convenience and speed in m-payment", Industrial Management \& Data Systems, Vol. 115 No. 2, pp. 311-331, 2015. DOI: 10.1108/IMDS-08-2014-0231

[93] Tewari, D. M., "Towards financial inclusion in India: the case of PMJDY", Journal of Economic Policy and Research, Vol. 10 No. 2, pp. 210-225, 2015. https://www.proquest.com/docview/1712757352?pq-origsi te $=$ gscholar $\&$ fromopenview $=$ true $\#$

[94] Thomas, R. \& Chatterjee, A., "Unified Payment Interface (UPI): A Catalyst Tool Supporting Digitalization-Utility, Prospects \& Issues", International Journal of Innovative 
Research and Advanced Studies, Vol. 4 No. 2, pp. 192-195, 2017.

http://www.ijiras.com/2017/Vol_4-Issue_2/paper_43.pdf

[95] Ting, D. S. W., Carin, L., Dzau, V., \& Wong, T. Y., "Dgtl. tech. \& COVID-19", Nature med., Vol. 26 No.4, pp 459-461, 2020. DOI: 10.1038/s41591-020-0824-5

[96] West, J., "How open is open enough?: Melding proprietary and open source platform strategies", Research policy, Vol. 32 No. 7, pp. 1259-1285, 2003. DOI: 10.1016/S0048-7333(03)00052-0

[97] Xu, X., "Trust and financial inclusion: A cross-country study", Finance Research Letters, Vol. 35 No. 1, pp. 101310, 2020. DOI: 10.1016/j.frl.2019.101310

[98] Yeung, G., He, C. \& Zhang, P., "Rural Banking in China:
Geographically Accessible but Still Financially Excluded?", Regional Studies, Vol. 51 No. 2, pp. 297-312, 2017. DOI: $10.1080 / 00343404.2015 .1100283$

[99] Zachariadis, M. \& Ozcan, P., "The API economy and digital transformation in financial services: The case of open banking", SWIFT Institute Working Paper, No. 2016-001, 2017. DOI: $10.2139 / \mathrm{ssrn} .2975199$

[100] Zhou, T., "An empirical examination of initial trust in mobile payment", Wireless personal communications, Vol. 77 No. 2, pp. 1519-1531, 2014. DOI: $10.1007 / \mathrm{s} 11277-013-1596-8$

[101] Zulfiqar, K., Chaudhary, M. A. \& Aslam, A., "Financial inclusion and its implications for inclusive growth in Pakistan", Pakistan Economic and Social Review, Vol. 54 No. 2, pp. 297, 2016. https://www.jstor.org/stable/26616711 